\title{
Digging Beneath the Surface: Analyzing the Complexity of Instructors' Participation in Asynchronous Discussion
}

\author{
Lane Whitney Clarke \\ Audrey Bartholomew \\ University of New England
}

\begin{abstract}
The purpose of this study was to investigate instructor participation in asynchronous discussions through an in-depth content analysis of instructors' postings and comments through the Community of Inquiry (COI) framework (Garrison et. al, 2001). We developed an analytical tool based on this framework in order to better understand what instructors were saying in discussions. We found instructors relied heavily on social codes and were less likely to employ cognitive codes, that there was a variance in the types of discursive interactions as indicated by different discursive profiles, and that students tended to favor instructors who balanced their comments across the three elements of the framework. We believe engaging in this type of analysis can help us become more effective online instructors and provide a next step for research investigating relationships between comments supporting the COI framework and student participation.
\end{abstract}

“The purpose of online discussions is to talk! If we didn't discuss, it would be a self-taught class”

- Online student from this study

"I try to be the teacher who sits in the circle on the floor and participates but doesn't dominate the discussion. It can be tricky to find the right balance sometime"

- Online instructor from this study

\section{Introduction}

As online education continues to grow, educators will constantly think about, analyze, and reflect upon pedagogical practices which push teaching and learning forward. Many of us believe in the social constructivist view where learning is a collaborative experience, not taking place in isolation but rather through interactions with others (Vygotsky, 1978). Through this lens, knowledge is constructed while individuals are engaging in activities, receiving feedback, and participating in other forms of human interaction in public social contexts (Henning, 2004). The student quote above sums this up nicelywithout social interaction, online education could become a "self-taught" learning experience. 
One instructional practice that has become vital in supporting this social constructivist approach to online learning is asynchronous discussions. Class discussions are a common way to engage students in learning communities (Cazden, 1988). In online learning, asynchronous discussions have become a common feature through which learning experiences are structured (King, 2002). However, many instructors struggle with how to find the "right balance" in facilitating such discussions. It can be tricky for instructors to find his or her role in these discussions in order to support a collaborative community and stimulate student interaction with the content and each other. As a result, the purpose of this descriptive study was to examine instructor comments and participation in asynchronous discussions. We believe that in order to understand the impact of instructor participation on student learning, we first need to have a richer understanding of the content within instructor comments. Previous studies have looked at surface level factors such as instructor comments versus questions, or the frequency of instructor participation. We believe this surface level analysis gives only a starting point for examining the instructor's role in discursive interactions. In this study we aim to provide an approach to look deeper into what an instructor says in asynchronous discussions. By developing an analytical tool based on the Community of Inquiry framework (Garrison, Anderson, \& Archer, 2001) we categorized the types of comments made by instructors as well as identified more complex profiles of instructor interaction. By understanding our own practice as instructors we will potentially be better able to make connections between our behaviors and how this impacts student learning and student satisfaction. We believe this study will enable others to better understand the transactional nature of asynchronous discussions and can lead to continued research on this important pedagogical approach used in many online learning environments. Through our investigation we hope to help instructors who also see participating in online discussions as a balancing act, and support the facilitation of online environments in which students are engaged in meaningful talk.

\section{The Importance of Asynchronous Discussions}

\section{Student Participation in Asynchronous Discussions}

Asynchronous discussions have found their place in online learning and have generated an extensive research base (Carr-Chellman \& Duchasteel, 2002; King, 2002; Paloff \& Pratt, 1999; Peterson, \& Slotta, 2009). Within this body of research there has been much focus around how students participate in these discussions. For example Vonderwell and Zachariah (2005) analyzed asynchronous discussions and identified various student participation profiles such as active participators, lurkers (i.e., those who read but do not post), and non-participators. Additionally, Peterson and Slotta (2009) found that while all students contributed at least one discussion board prompt, the number of responses students received from peers ranged widely. The number of peer responses to an initial post appeared to depend on the frequency and timing of students' contributions. They continued to examine the quality of responses and categorized these into three groups: personal connection to the reading, knowledge building notes, and relationship building notes. Thomas (2002) investigated student participation in asynchronous discussions and found that over the course of a semester, discourse patterns shifted from an overtly academic, highly structured tone to a more familiar pattern of interaction. Hew, Cheung, and Ng (2010), identified the factors that limited student contribution in asynchronous discussions in order to better understand how students engage in these discussions. These studies represent a small sampling of the research base on student involvement in discussions; however these few studies indicate that research has been undertaken on student participation that goes beyond the surface level of participation. By identifying student profiles, patterns or interaction, and types of comments we get a richer understanding of how students participate in discussions. However, this is just one side of the equation-we also need to understand the other side of this social interaction: that is, the instructor.

\section{Instructor Participation in Asynchronous Discussions}

While studying how students interact in asynchronous discussions is an important line of research it is also equally important to understand the instructor's role in discussions. There seems to be two lines 
of research developing in this area. First, some researchers have looked at how an instructor's presence impacts students' learning and engagement. The findings around this question seem to be mixed. For example, there has been research indicating students' reporting of learning and satisfaction improves when they have more interaction with their instructor (Moore, 2002; Swan, 2001), when instructors motivate students in asynchronous discussions (Wu \& Hiltz, 2004), and when a discussion board is moderated by an instructor (Wise et al., 2006). Jiang and Ting (2000) found the number of instructor responses had a strong relationship with the number of student responses although they cautioned this finding was based on a small amount of data. These positive findings; however, have been contradicted by two larger studies done by Mazzolini and Madison (2003, 2007). In their 2003 study, Mazzolini and Madison categorized instructor participation as either "sage on the stage", "guide on the side", or "ghost in the wings". They wanted to find out if these types of participation styles by the instructor impacted students' rate of posting, length of posts, and student perception. This study indicated instructor's actual postings had little correlation with the rate or length of student posts. In a follow up study (2007) they examined the content of instructor posts; however, they only categorized posts as questions, comments, or neither. Similar to the first study, they found that none of these types of posts influenced the rate and length of students' posts. They also looked at frequency (i.e., how often) and timing (i.e., when was the best time to post). They found as an instructor's posts increased, it was more likely the students' posts decreased in frequency and length. Similarly, An, Shin, \& Lim (2009) found when instructors participated a lot in discussions students tended to answer more of the instructor's comments and not as many of their peers comments. This notion of the instructor's participation contributing to decreased student participation has also been echoed in similar research (Dixon, 2006: Fauske \& Wade, 2003-2004; Li, 2003).

The second line of research has led researchers to look more deeply at these discussions beyond the frequency and surface features of instructor participation. For example, Arend (2009) looked closely at the differences in instructor facilitation and found that it was not the frequency of an instructor's comment that impacted a discussion but rather there were general facilitation characteristics that promoted critical thinking in student discussions. In an effort to identify these characteristics, Nandi, Hamiliton, \& Harland (2012) examined the quality of asynchronous discussions and identified themes related to instructor participation. The researchers indicated nine themes such as providing feedback with an example, periodic intervening to direct and extend discussions, and promoting deep learning. They found that instructors did play an active role in initiating and carrying a discussion forward and validated the belief that the role of the instructor is an important one.

\section{Community of Inquiry Model}

One possible way to further analyze how instructors participate in discussions is to use the Community of Inquiry (COI) framework. Garrison, Anderson, \& Archer (2000) developed this framework in an attempt to establish a process for how students construct knowledge. This process is based on John Dewey's work on community and inquiry, and extends it to online asynchronous courses (Garrison, Anderson, \& Archer, 2010). The COI is constructed by three elements: social presence, teaching presence, and cognitive presence. All three presences interact and are interconnected and influenced by each other (Garrison \& Arbaugh, 2007).

Research has indicated the COI is a valid way of analyzing the different elements of an online course. For example, Arbaugh et al. (2008) developed a 34 item survey asking students to indicate their level of agreement with statements regarding the three different presences (e.g., "Online or web-based communication is an excellent medium for social interaction”). A factor analysis confirmed the framework to be a valid model for developing and delivering a course, though results did also indicate a need for teaching presence to be better refined. Some additional issues with the COI framework have been noted, particularly the argument that the COI does not contribute to deep and meaningful learning (Rourke \& Kanuka (2009); however, there is a research linking the framework with student outcomes and/or satisfaction (Akyol \& Garrison, 2011; Shea, 2006; Shea, Li, \& Pickett, 2007). 
In addition to research on the framework as a whole, there also has been research examining each presence by itself. Social presence can be defined as establishing personal and purposeful relationships with both peers and instructor. The original categories include affective expression, open communication, and group cohesion (Garrison \& Arbaugh, 2007). Research has indicated making this social connection is an instrumental foundation that can potentially lead to more effective learning (Swan \& Shih, 2005). Recent research has suggested different indicators of social presence are concentrated at different points in a course (i.e., affective expression may decrease while group cohesion increases; Akyol \& Garrison, 2011).

Teaching presence is directly related to student satisfaction and learning. Because of the lack of proximity in online learning, it is important that a teacher is cognizant of how his or her teaching presence manifests in an online environment. According to Garrison's model there are three categories within this domain: design, facilitation, and direct instruction. Recent research has indicated teaching presence needs to be better defined (Arbaugh et al., 2008) and in fact a fourth category has been suggested: assessment (Shea, Vickers, \& Hayes, 2010)

While most research on teaching presence has focused on discussions and announcements as areas of teaching presence, there is research to suggest teaching presence indicators can be found across the course (e.g., course emails, private folders) and levels of this presence can be maintained at a high rate even for an instructor who has little participation in threaded discussions (Shea, Vickers, \& Hayes, 2010).

Cognitive presence is defined as "the exploration, construction, resolution, and confirmation of understanding through collaboration and reflection” (Garrison, Anderson \& Archer, 2000, p. 65). This presence is based on the Practical Inquiry Model and includes four phases: triggering, exploration, integration, and resolution (Garrison \& Arbaugh, 2007). Although research has suggested little evidence of students reaching the resolution phase, there is some research indicating different activities can facilitate students reaching the different phases. For example, Archibald (2010) found a higher number of students reaching the resolution phase in case-based discussions versus open-ended discussions.

In addition to using the COI to examine the effectiveness of an entire course, there has been research identifying how this framework can be used to examine just asynchronous discussions. Because so much of instructor participation in discussions can be classified as facilitating discourse, it is easy to assume asynchronous discussions are largely comprised of teaching presence indicators (Shea, Vickers, \& Hayes, 2010). However, there has been research indicating discussions contribute to the two remaining presences: social and cognitive. First, Swan (2003) analyzed a sample of asynchronous discussions postings and identified an average of six social presence indicators per message. Darabi, Arrastia, Nelson, Cornille, \& Liang (2010) drew on the Community of Inquiry (COI) model to examine how the structure of a discussion impacts cognitive presence. They found asynchronous discussions can engage students in three of the four cognitive presence phases.

This current study attempts to further this research by examining instructor participation only and identify how we can understand this participation through the COI framework. We are interested in knowing more about how an instructor can encourage and support engagement and motivate through these discussions, but we believe that we need to look deeper into the content of these discussions in order to find this answer. Like Nandi, Hamilton, \& Harland (2012), we strive to look at themes and patterns that go beyond Mazzolini and Madison's (2003) guide on the side, and sage on the stage or simply looking at questions or comments (2007). We also believe that like Darabi, et al. (2010) the COI is an effective framework to look more closely at instructor participation. In this study we offer a more nuanced approach to understanding instructor discursive patterns beyond instructor participation. We believe that we also need to look at what the instructor actually says before we can make broad conclusions about an instructor's influence on a discussion and use the COI framework as a lens through which to investigate. The goal of this study is to take this first step and help others more closely analyze how an instructor participates in asynchronous discussions. Once we have a way to represent this complexity, then we believe additional research can provide us with a deeper understanding of this discursive event. 


\section{Our Study}

The purpose of this study was to add to the existing research on instructor participation in asynchronous discussions by doing an in-depth analysis of the content of instructors' postings and comments. There were several goals of this research. First, we wanted to better understand what instructors were saying in asynchronous discussions by engaging in a content analysis based on the Community of Inquiry (COI) model (Garrison et. al, 2001). Second, as a result of this content analysis, we wanted to develop a user-friendly tool that can be used by other instructors to analyze their own participation in asynchronous discussions. The third goal of this study was to lay a detailed foundation for subsequent research on the different ways instructor participation can influence student participation. Finally, we hope this research will encourage instructors to become more effective in their participation in asynchronous discussions to improve engagement and deepen knowledge for students.

\section{Tool Development}

In order to investigate instructor participation in asynchronous discussions, we developed an analytical tool based on the Community of Inquiry (COI) framework. We had two goals in the development of this tool. First, we wanted a tool which would allow us to more closely analyze the content of an instructor's comments. Second, we hoped that this tool could be shared with others who wished to do the same. We knew that in order to capture the richness of how an instructor participates in asynchronous discussions we needed to look beyond the surface features of discussion (e.g., length, frequency, question, or comment). By basing our tool in the COI framework, we were confident this would assist us in providing a deeper understanding of what instructors were saying and how they were engaging in asynchronous discussions with their students.

The development of the tool occurred in multiple phases:

- Deciding on Codes: Once the Community of Inquiry (COI) Model was identified as a framework to drive our analytical tool, we established discursive codes that would correspond with each of the broad categories of types of comments. First, we identified and reviewed previous research that used discursive codes to analyze data (Dixson, et al., 2006; Meyer, 2003; Wang \& Chen, 2008). This review led to a list of potential codes. Then we took each of these codes and put them under each category (i.e., teacher, cognitive, social). We vetted this list of codes over multiple rounds until we had a working list of codes.

- Operationalizing Codes: Once we had a working list of codes, we sought to define and pilot each code using discussion samples from a different course. We went through multiple rounds of practice coding to determine if codes did or did not fit the assigned category from the COI model. A coding notation was developed for each code along with a definition of the code and a discursive exemplar for illustrative purposes.

- Trial Runs with Codes: After the codes were developed and piloted successfully, we then conducted another coding trial run using asynchronous discussions from a previous course. These practice rounds were conducted independently. After each round we came together to reconcile codes, refine definitions and exemplars, and reach consensus.

- $\quad$ Validating the instrument: After multiple trial runs we achieved inter-rater reliability of $80 \%$ on independent coding. 
Figure 1 Coding Categories for Analytical Tool

\begin{tabular}{|c|c|c|c|c|}
\hline $\begin{array}{l}\text { Cognitive } \\
\text { Codes }\end{array}$ & \multicolumn{4}{|c|}{$\begin{array}{l}\text { Exploration, construction, resolution, and confirmation of understanding through } \\
\text { collaboration and reflection }\end{array}$} \\
\hline Code & & Purpose & Do your comments... & Example \\
\hline $\begin{array}{l}\text { Challenging/ } \\
\text { Probing }\end{array}$ & $\mathbf{C H}$ & $\begin{array}{l}\text { Challenging or } \\
\text { probing students to } \\
\text { think deeper about } \\
\text { a topic/issue. }\end{array}$ & $\begin{array}{l}\text { Use signal words } \\
\text { like: I wonder, what } \\
\text { do you } \\
\text { think...usually } \\
\text { followed by a } \\
\text { question. }\end{array}$ & $\begin{array}{l}\text { One thing I wonder though is } \\
\text { the balance between the texts } \\
\text { that we give to kids at their } \\
\text { instructional level and the } \\
\text { complex texts that we need } \\
\text { to use. What have you found } \\
\text { to be the right balance? }\end{array}$ \\
\hline $\begin{array}{l}\text { Student } \\
\text { Elaboration }\end{array}$ & SE & $\begin{array}{l}\text { Exploring a topic } \\
\text { deeper }\end{array}$ & $\begin{array}{l}\text { Asking students to } \\
\text { elaborate on a topic } \\
\text { or idea the student } \\
\text { mentioned in their } \\
\text { post with the intent of } \\
\text { having think deeper } \\
\text { on the topic }\end{array}$ & $\begin{array}{l}\text { I am curious what your } \\
\text { colleagues say about } \\
\text { building background } \\
\text { knowledge and the role it } \\
\text { plays in comprehension } \\
\text { instruction? }\end{array}$ \\
\hline Questioning & $\mathbf{Q}$ & $\begin{array}{l}\text { Extending thinking } \\
\text { around a topic or } \\
\text { issue }\end{array}$ & $\begin{array}{l}\text { Asking students a } \\
\text { question but the } \\
\text { answer does not } \\
\text { require an } \\
\text { elaboration. }\end{array}$ & $\begin{array}{l}\text { I assume you find this } \\
\text { effective? }\end{array}$ \\
\hline $\begin{array}{l}\text { Teaching } \\
\text { Codes }\end{array}$ & \multicolumn{4}{|c|}{ Design, facilitation, direct instruction of learning } \\
\hline Code & & Purpose & Do your comments... & Example \\
\hline $\begin{array}{l}\text { Pulling } \\
\text { Together }\end{array}$ & PT & $\begin{array}{l}\text { Summarizing or } \\
\text { pulling together } \\
\text { a student or } \\
\text { multiple } \\
\text { students' ideas. }\end{array}$ & $\begin{array}{l}\text { Refer directly to one } \\
\text { or more student ideas } \\
\text { to make a point }\end{array}$ & $\begin{array}{l}\text { I think what you are trying to } \\
\text { say is echoed in (another } \\
\text { student's) post. }\end{array}$ \\
\hline $\begin{array}{l}\text { Providing } \\
\text { Resources }\end{array}$ & PR & $\begin{array}{l}\text { Adding } \\
\text { information or } \\
\text { details to a } \\
\text { discussion }\end{array}$ & $\begin{array}{l}\text { Provide a tangible } \\
\text { link or resource to } \\
\text { elaborate on a topic. }\end{array}$ & $\begin{array}{l}\text { Here is where you can go for } \\
\text { more information.... }\end{array}$ \\
\hline
\end{tabular}




\begin{tabular}{|c|c|c|c|c|}
\hline $\begin{array}{l}\text { Sharing } \\
\text { Ideas }\end{array}$ & SI & $\begin{array}{l}\text { Directing } \\
\text { students to } \\
\text { provide more } \\
\text { information by } \\
\text { sharing with } \\
\text { them your } \\
\text { thoughts }\end{array}$ & $\begin{array}{l}\text { Provide an idea for } \\
\text { the student to do in } \\
\text { their own practice }\end{array}$ & $\begin{array}{l}\text { Maybe you can take photos } \\
\text { of what active reading does } \\
\text { NOT look like- that might be } \\
\text { powerful too! }\end{array}$ \\
\hline $\begin{array}{l}\text { Teacher } \\
\text { Elaboration }\end{array}$ & TE & $\begin{array}{l}\text { Expanding on an } \\
\text { idea to make a } \\
\text { point. Goes } \\
\text { beyond } \\
\text { confirmation of } \\
\text { the student } \\
\text { response and } \\
\text { typically uses an } \\
\text { example to } \\
\text { illustrate the } \\
\text { point. }\end{array}$ & $\begin{array}{l}\text { Build on students } \\
\text { comments but } \\
\text { provide illustrative } \\
\text { examples or ideas in } \\
\text { order to teach a } \\
\text { concept }\end{array}$ & $\begin{array}{l}\text { One thing that caught my } \\
\text { attention was what you said } \\
\text { about resiliency. I just read a } \\
\text { great article on the } \\
\text { importance of giving our } \\
\text { kids texts that they struggle } \\
\text { with. We do so much } \\
\text { modeling, and background } \\
\text { knowledge building, } \\
\text { and vocabulary scaffolding } \\
\text { that sometimes we don't let } \\
\text { our students } \\
\text { wrestle interdependently wit } \\
\text { h tough texts and perhaps we } \\
\text { are doing them a disservice } \\
\text { by not helping them build up } \\
\text { their resiliency. }\end{array}$ \\
\hline $\begin{array}{l}\text { Technical } \\
\text { Assistance }\end{array}$ & TA & $\begin{array}{l}\text { Helping with } \\
\text { technology }\end{array}$ & $\begin{array}{l}\text { Address technology } \\
\text { or computer issues }\end{array}$ & $\begin{array}{l}\text { Have you tried using a } \\
\text { different browser? }\end{array}$ \\
\hline Connections & CON & $\begin{array}{l}\text { Deepening } \\
\text { understanding by } \\
\text { making } \\
\text { connections } \\
\text { between new } \\
\text { knowledge and } \\
\text { established } \\
\text { understandings, } \\
\text { experiences, or } \\
\text { knowledge }\end{array}$ & $\begin{array}{l}\text { Making a connection } \\
\text { within the course } \\
\text { (e.g., between two } \\
\text { posts, a post and the } \\
\text { text, a post and a } \\
\text { larger issue in the } \\
\text { field). }\end{array}$ & $\begin{array}{l}\text { As to you question about } \\
\text { background knowledge -- - } \\
\text { this is one that has been } \\
\text { brewing in the literacy world } \\
\text { as a result of the CCSS. }\end{array}$ \\
\hline Social Codes & \multicolumn{4}{|c|}{$\begin{array}{l}\text { Ability to project one's self and establish personal and purposeful relationships- } \\
\text { end result in building an effective learning community }\end{array}$} \\
\hline
\end{tabular}




\begin{tabular}{|c|c|c|c|c|}
\hline Code & & Purpose & Do your comments... & Example \\
\hline $\begin{array}{l}\text { Encouragem } \\
\text { ent }\end{array}$ & $\mathbf{E}$ & $\begin{array}{l}\text { Trying to get a } \\
\text { student to do } \\
\text { something } \\
\text { through positive } \\
\text { reinforcement }\end{array}$ & $\begin{array}{l}\text { Use a positive tone, } \\
\text { celebrate, provide } \\
\text { supportive ideas, use } \\
\text { emoticons or } \\
\text { explanation points }\end{array}$ & $\begin{array}{l}\text { Maybe you can take photos } \\
\text { of what active reading does } \\
\text { NOT look like- that might be } \\
\text { powerful too! }\end{array}$ \\
\hline $\begin{array}{l}\text { Drawing in } \\
\text { participants }\end{array}$ & DIP & $\begin{array}{l}\text { Trying to get } \\
\text { others involved } \\
\text { in the } \\
\text { discussion- } \\
\text { really only refers } \\
\text { to a statement } \\
\text { that specifically } \\
\text { asks for more } \\
\text { students to offer } \\
\text { their response. } \\
\text { Words to look } \\
\text { for- we, us, you } \\
\text { all }\end{array}$ & $\begin{array}{l}\text { Address others in the } \\
\text { class? Ask questions } \\
\text { to more than one } \\
\text { person? }\end{array}$ & $\begin{array}{l}\text { How do you all ensure that } \\
\text { this follow up/reflective part } \\
\text { actually happens- any } \\
\text { classroom strategies that you } \\
\text { all have used?? }\end{array}$ \\
\hline \multirow[t]{2}{*}{ Compliment } & $\begin{array}{l}\text { COM } \\
-S C\end{array}$ & $\begin{array}{l}\text { Social } \\
\text { Compliment- } \\
\text { Providing a } \\
\text { compliment with } \\
\text { the goal of } \\
\text { praising, } \\
\text { inspiring } \\
\text { intimacy, } \\
\text { validating, } \\
\text { naming the } \\
\text { student, and/or } \\
\text { drawing student } \\
\text { into the learning } \\
\text { community }\end{array}$ & $\begin{array}{l}\text { Start with I, is } \\
\text { positive in tone, } \\
\text { celebrates a specific } \\
\text { point or idea }\end{array}$ & $\begin{array}{l}\text { I am glad you are finding this } \\
\text { book helpful } \\
\text { I love your example } \\
\text { Wonderful idea! } \\
\text { Thanks for sharing this! }\end{array}$ \\
\hline & $\begin{array}{l}\text { COM } \\
- \text { TC }\end{array}$ & $\begin{array}{l}\text { Teaching } \\
\text { Compliment- } \\
\text { Providing a }\end{array}$ & $\begin{array}{l}\text { Start with I, is } \\
\text { positive in tone, } \\
\text { celebrates a specific } \\
\text { point or idea but then }\end{array}$ & $\begin{array}{l}\text { You raise a great point about } \\
\text { how difficult it is to find } \\
\text { those comfortable texts as } \\
\text { oral reading and }\end{array}$ \\
\hline
\end{tabular}




\begin{tabular}{|l|l|l|l|l|}
\hline & & $\begin{array}{l}\text { compliment to } \\
\text { set up for a more } \\
\text { instructive } \\
\text { statement with a } \\
\text { teaching point } \\
\text { and/or bringing } \\
\text { some content } \\
\text { from the course. }\end{array}$ & $\begin{array}{l}\text { launch into a topic or } \\
\text { idea connected to the } \\
\text { content }\end{array}$ & $\begin{array}{l}\text { silent comprehension do } \\
\text { develop at different rates }\end{array}$ \\
\hline $\begin{array}{l}\text { Social } \\
\text { Information }\end{array}$ & SI & $\begin{array}{l}\text { Giving personal } \\
\text { and/or social } \\
\text { information in } \\
\text { effort to be part } \\
\text { of a learning } \\
\text { community }\end{array}$ & $\begin{array}{l}\text { Use I, share } \\
\text { something from your } \\
\text { life that may or may } \\
\text { not be attached to the } \\
\text { course content }\end{array}$ & $\begin{array}{l}\text { This winter is killing me too- } \\
\text { warm- I think we are all in } \\
\text { the same boat! }\end{array}$ \\
\hline $\begin{array}{l}\text { Personal } \\
\text { Experience }\end{array}$ & PE & $\begin{array}{l}\text { Using an } \\
\text { example from } \\
\text { your life- more } \\
\text { specific level } \\
\text { elaboration }\end{array}$ & $\begin{array}{l}\text { Use I, share } \\
\text { something from your } \\
\text { life that is attached to } \\
\text { the content }\end{array}$ & $\begin{array}{l}\text { There are so many times that } \\
\text { I have run out of time and } \\
\text { then don't get to debrief too! }\end{array}$ \\
\hline
\end{tabular}

\section{Methodology}

The data used for this study came from five sections of a required course in an online Masters of Education program with a concentration on literacy, EDU743: Connecting Writing with Reading for Success. The students in this study were all practicing K-12 teachers, from across the United States and Canada, working towards a master's degree or Certificate of Advanced Graduate Study in Education. This particular course had five sections with five different instructors teaching from the same course shell (i.e., they all taught from the same content, organization, and discussion questions) with approximately twenty students per section. All course instructors were female and had between five and ten years experience teaching in an online setting. Four of the instructors were adjunct and also worked as teachers in K-5 classrooms. One of the instructors was an Assistant professor, as well as one of the authors of this paper. This course was chosen for a number of reasons. First, it was a mature course, meaning it had been taught numerous times by all instructors. Therefore, all instructors had a strong knowledge of the course's content and organization. Second, because the course content focused on writing there tended to be more robust written discussions. Third, this course was a popular course and had multiple sections which enabled us to look at the same course across multiple instructors. All discussions were conducted on a weekly schedule and were part of the students' grade. Each discussion was assessed using a rubric that identified the criteria for an initial substantive post as well as engaged dialogue. Student discussion participation was not analyzed for this study but students were asked to voluntarily complete an anonymous survey. The data sources for this study included the following:

- $\quad$ printed discussions from three different, one-week modules from the five courses (this totaled 34 single spaced pages and 18,322 words)

- survey results of student perceptions of their instructor's participation in asynchronous discussions (the survey included three Likert questions relating to each code as well as three open 
ended questions about student perceptions of online discussions)

- survey results of instructors' perceptions about his or her participation in asynchronous discussions (also included three Likert questions and three open ended questions)

- official course evaluations (three questions from the course evaluations were specifically included to gauge student perception of his/her instructor's engagement in these discussions)

This data set enabled us to analyze patterns and themes and generate some conclusions we hope others will find helpful.

\section{Data Analysis}

Data analysis consisted of several steps. First, each instructor was assigned a pseudonym and identifying information was removed. Second, instructor comments were entered into a database. Third, the analytical tool (see Figure 1), based on the COI model, was created in order to facilitate analysis. Once the tool was created we engaged in coding the transcripts based on Strauss and Corbin's (1994) model of grounded theory. The process was as follows:

1. Selective coding: First, the co-researchers used the analytical tool to code a transcript apart from the data set to establish code agreement. Once agreement was established, each researcher then coded each set of sample transcripts and then switched to cross code each transcript. We continued to cross code sample transcripts until we reached a $75 \%$ agreement in our coding process when coding the same transcripts.

2. Field Notes: Once the codes were established, transcripts were randomly assigned to both researchers and coded. To establish inter-rater reliability, $20 \%$ of transcripts were cross-coded until an agreement of 75\% was reached. As each researcher engaged in coding, she kept detailed field notes. These memos and observations were shared between researchers in weekly meetings.

3. Themes: Themes and patterns were identified from the coding notes and participation profiles were established. Researchers checked these themes against previous research as well as and the coding categories.

\section{Limitations}

As in any research endeavor there are limitations to this study. First, it is important to recognize that the content of a course can greatly influence the results. This course was a course in education where both the students and the instructor are all elementary and secondary teachers. Every community has a discursive identity and the way a teacher talks to another teacher is very different from the way two mathematicians or two historians may engage in discussion. Nandi, Hamilton, and Harland (2012) emphasize that the content of courses can impact how discussions take place. Second, another variable that was not accounted for is the impact of personal approaches and how these shaped the way instructors engaged and supported discussions. Vlachopoulos \& Cowen (2010) investigated personal teaching philosophies and found that different facilitators had different approaches based on these approaches. While we did ask our instructors about their goals for discussion we did not dig deeply into their personal philosophies. Also, all of our instructors were women and there has been much research on gender as it relates to discursive practices. Third, other factors such as timing of posts, differences in discussion topics, and how the instructors' comments influenced student discussions were also not considered in this research. Discussion is complex and there are many factors that influence how it occurs in any setting. Fourth, in addition, although we developed a level of agreement before coding and also exchanged a sample of transcripts to establish inter-rater agreement, the threat of observer bias still exists. We chose to calculate inter-rater agreement rather than analyze our results with statistics such as Cohen's kappa. Additionally, our definition of what constituted as certain indicators may not be in agreement with the instructors and/or students. Issues with social presence particularly may exist as it has been suggested that this aspect may be a matter of individual perceptions by students (Gunawardena, Lowe, \& Anderson, 1997). For example, what we may have considered as encouraging may not be the same for all of the 
students in the course. Finally, this study does not set out to establish any type of causal relationship between instructor participation and student engagement or achievement, nor do we attempt to make broad statements about all instructors as they participate. We do, however, wish to present a model for examining instructor participation and share how this tool helped us better understand how we participate in asynchronous discussions.

\section{Results}

The results of our analysis are organized around four questions:

1. What is the instructor saying in these discussions?

2. How do instructors interact differently in these discussions?

3. How do the students perceive the instructor's participation in these discussions?

4. How do the instructors perceive their roles in these discussions?

In order to answer the first two questions, we drew upon the coding categories that were generated as a result of our content analysis. First, we present the codes that were most and least common overall for all instructors. Then we focus on individual instructors and the differences in patterns of interaction between the five. Next, we analyze the survey data to understand how students perceive their instructor's roles in these discussions. Finally, we draw on survey data to better understand how the instructors see their role in these discussions. By addressing these four questions, we are able to draw some conclusions and make recommendations as to further research in this area.

When we look at the types of codes instructors used overall we see some patterns. By looking at Table 1, we see some trends across instructors. First, the frequency of each category is presented as an average across instructors. Social comments were the most common (average of 52.6\%). In the table, the frequency of each type of comment within each category is also represented. Within the social comment category, teaching compliments were delivered the most frequently (average of 25.5\%). Teaching compliments (see Figure 1 for elaboration on each code) are defined as compliments that not just lead to social cohesion of the group but also serve as a spring board to a teaching point or to pull in some content. Here is an example of a teaching compliment from a transcript, "You raise a great point about how difficult it is to find those comfortable texts as oral reading and silent comprehension do develop at different rates." The instructor started this interaction by complimenting the student on the point he or she raised. Then she continued to point out that oral and silent reading comprehension develops differently, thus using this interaction to teach a concept. Because of the distinct differences in compliments, we decided to differentiate compliments as either a teaching compliment or purely a social compliment (e.g., “Great job” or "Nice contribution"). Teaching compliments were the most common code amongst all comments regardless of category. The second most common type of comment within the social category was personal experience (average of $11.6 \%$ ). Many of the instructors shared their own experiences in the classroom to connect with students. An example of this was when one student commented on the lack of time he/she had to teach and the instructor added, "There are so many times that I have run out of time and then don't get to debrief too!” 
Table 1 Frequency of comments by category and instructor

Type of comment Instructor

\begin{tabular}{|c|c|c|c|c|c|c|c|}
\hline & Jay & Hawk & Dove & Eagle & Owl & Total & Average \\
\hline Cognitive & 1 & $\mathbf{0}$ & 33 & 24 & 2 & 60 & 11.6 \\
\hline Challenging/Probing & 1 & 0 & 10 & 0 & 0 & 11 & 2.1 \\
\hline Student Elaboration & 0 & 0 & 19 & 18 & 1 & 38 & 7.4 \\
\hline Questioning & 0 & 0 & 4 & 6 & 1 & 11 & 2.1 \\
\hline Teaching & 6 & 2 & 61 & 103 & 11 & 183 & 35.4 \\
\hline Pulling together & 0 & 0 & 0 & 0 & 0 & $\mathbf{0}$ & $\mathbf{0}$ \\
\hline Providing resources & 0 & 0 & 4 & 10 & 0 & 14 & 2.7 \\
\hline Sharing Ideas & 2 & 0 & 0 & 10 & 1 & 13 & 2.5 \\
\hline Teacher elaboration & 3 & 2 & 48 & 69 & 9 & 131 & 25.3 \\
\hline Teaching assistance & 0 & 0 & 0 & 0 & 0 & $\mathbf{0}$ & $\mathbf{0}$ \\
\hline Connections & 1 & 0 & 9 & 14 & 1 & 25 & 4.8 \\
\hline Social & 6 & 2 & 49 & 194 & 21 & 272 & 52.6 \\
\hline Encouragement & 0 & 0 & 2 & 3 & 2 & 7 & 1.4 \\
\hline $\begin{array}{l}\text { Drawing in } \\
\text { Participants }\end{array}$ & 0 & 0 & 6 & 23 & 0 & 29 & 5.6 \\
\hline Social compliment & 0 & 1 & 19 & 10 & 10 & 40 & 7.7 \\
\hline Teaching compliment & 0 & 1 & 22 & 105 & 8 & 136 & 25.5 \\
\hline Social Info & 0 & 0 & 0 & 0 & 0 & $\mathbf{0}$ & $\mathbf{0}$ \\
\hline Personal experience & 6 & 0 & 0 & 53 & 1 & 60 & 11.6 \\
\hline Total: & 13 & 6 & 143 & 321 & 34 & 517 & \\
\hline Average: & 2.5 & 1.1 & 27.7 & 62.1 & 6.6 & & \\
\hline
\end{tabular}


Overall, the second most common category of code was teaching (average of 35.4\%). We considered teaching codes to be those whose purpose was to facilitate and direct student learning. Overall, the most common code in this category, and the second most common type of comment overall, was teacher elaboration (average of 25.3\%). Teacher elaboration occurred when the instructor took an idea and expanded on the idea in order to make a point. These comments were different from teacher compliments as the goal of these comments were not to build social cohesion in the group but rather to engage in an opportunity to direct discussion and thinking around a topic. For example, in the comment below the instructor picks up on a statement a student made and uses his/her comment as a jumping off point to introduce an article and elaborate on the topic of resiliency:

One thing that caught my attention was what you said about resiliency. I just read a great article (and I do not have it with me but will look for it when I go into my office tomorrow to attach) on the importance of giving our kids texts that they struggle with. We do so much modeling, and background knowledge building, and vocabulary scaffolding that sometimes we don't let our student wrestle independently with tough texts and perhaps we are doing them a disservice by not helping them build up their resiliency.

The least common category of codes was cognitive codes (average of 11.6\%). The goals of cognitive codes were to support student exploration, construction, resolution, and confirmation of understanding through collaboration and reflection. While the codes in this category were used least frequently, the highest type of comment made was student elaboration (average of 7.4\%). When an instructor engaged in student elaboration she asked students to elaborate in order to get the students to move their discussions to a deeper level. For example, one instructor asked a student to probe more deeply into what others in her building were doing around background knowledge. One example is, "I am curious what your colleagues say about building background knowledge and the role it plays in comprehension instruction?” We defined elaboration different from just asking a question that may or may not have had more than a simple answer.

\section{How Do Instructors Interact Differently in These Discussions?}

We used the COI tool to analyze what codes instructors tended to use overall. We then used this tool to more closely examine how instructors engaged differently in these discussions. As mentioned in the methodology, all of the instructors were teaching the same course, with the same content, using the same discussion questions, at the same time. However, the way instructors engaged in discussions was radically different.

When we first looked at the overall data we noticed a huge discrepancy in the rate of participation of our five instructors. Eagle, the most active commenter, made a total of 321 comments. Dove, the second most frequent poster, made 143 comments, Owl made 34 comments, Jay made 13, and Hawk made only 6 comments in the same time period. Clearly the instructors had dramatically different posting frequencies.

In order to dig deeper into the content of instructors' posts, we examined the frequency of the types of comments made by each instructor and created a profile of how each instructor typically constructed her post. First, the most prolific poster, Eagle, used social presence comments (194) and teaching comments (103) most frequently, with only 24 cognitive comments. The following profile demonstrates a typical comment by Eagle. This exemplar demonstrates her use of positive reinforcement and elaboration with the goal of connecting with students and also finding ways to teach through examples. For illustrative purposes our coding is in brackets.

I love your ah-ha moments. I think that we do tend to communicate a very narrow definition of what writing is (or at least our testing does). [S-Teacher Compliment] When kids say they don't like to write they tend to think about the 5 paragraph essay or going through all of the parts of the writing process- but writing is as diverse as reading and we need to communicate this to them. I also really connected to the writing process comment. [T-Teacher Elaboration] I actually enjoy 
the process of writing. I like to start with a blank page and then see what I have at the end very satisfying. [S-Personal Experience] I also liken this to sculpting with clay- start out with a blob and then work it into something that actually has form and substance- again the process is the satisfying part for me. [S-Personal Experience]

What was interesting about Dove was that this instructor was not just the second highest poster but the one instructor who tended to balance all three codes most evenly. She had 33 cognitive codes (which was the highest number amongst all instructors), 61 teaching codes, and 49 social codes. This balance of interaction is seen in the exemplar below, where she starts with a social code, moves into a teaching code, and ends with a cognitive code.

Karen, you bring up an important point about the connections between reading, writing and oral language. [S-Teaching compliment] All three processes occur as a part of a child's literacy development and it's important for us as educators to promote these connections. [T-Teacher Elaboration] I like the way you focus on authentic forms of writing so that your students will understand the many ways in which written communication is a part of our lives. [T-Teaching Compliment] What are some of the ways that you (and anyone else as well) establish and support the connections between reading, writing and oral language? [C-Student elaboration]

Owl made 34 comments and 21 of these were social comments (double that of her next highest comment type: teaching). Owl's comments tended to be very positive and upbeat giving lots of social comments to her students. This instructor also tended to start all of her posts by addressing the student by name. For example, in the below example, she begins with a compliment to Lisa and then goes into her teaching elaboration and then concludes with another compliment.

Lisa-You make some excellent points based on what was striking to you in your reading[S-Social Compliment]. I think use of models is so important. It's the first stage in the Gradual Release of Responsibility with the latter two (some say three) being we do together (with teacher support/feedback) and you do independently. [T-Teacher Elaboration] Love that model! [SSocial Compliment]

Jay made very few comments (13) and these were pretty evenly split between teaching (6) and social (6). This instructor did a lot of personal sharing as the following exemplar highlights.

Wendy, I also have very little wall space for student work so I have been doing more writing share at the end of workshop days. I also try to have something up in the hallway bulletin board to showcase their writing work. We make a lot of books as well!

Hawk made a total of six comments; two of those were teacher elaboration comments, two were social compliments, and two were teaching compliments. It is unclear why this instructor posted so infrequently. As a result we were not able to look more closely at this instructor's pattern of responses.

\section{How Do the Students Perceive the Instructor's Participation in These Discussions?}

In addition to looking at what the instructors said in these discussions, we were also interested in knowing how students perceived their instructor's participation. We asked students to comment on how their instructor's participation in asynchronous discussions impacted their higher level thinking and engagement with the content. We also asked students to reflect on how engaged they believed their instructors were in these discussions. 
Table 2.1 Student perceptions of how their instructor's comments encourage in-depth thinking on the topic.

\begin{tabular}{|c|c|c|c|c|c|}
\hline \multirow[t]{2}{*}{ Instructor } & \multicolumn{5}{|c|}{ Level of Agreement } \\
\hline & $\begin{array}{l}\text { Strongly } \\
\text { agree }\end{array}$ & Agree & $\begin{array}{l}\text { Neither agree } \\
\text { nor disagree }\end{array}$ & Disagree & $\begin{array}{l}\text { Strongly } \\
\text { Disagree }\end{array}$ \\
\hline Owl & 21 & 26 & 42 & 5 & 0 \\
\hline Jay & 25 & 25 & 35 & 0 & 5 \\
\hline Hawk & 29 & 29 & 33 & 5 & 0 \\
\hline Dove & 47 & 40 & 13 & 0 & 0 \\
\hline Eagle & 58 & 37 & 0 & 5 & 0 \\
\hline Average & 36 & 31.4 & 24.6 & 3 & 1 \\
\hline
\end{tabular}

First, we asked students to reflect on how their instructor's comments in the discussions encouraged in-depth thinking on each topic (Table 2.1). We broke down the results by instructor and represented these responses by percentages. While the results for Owl, Jay, and Hawk were pretty even with similar percentages of students agreeing or strongly agreeing, Dove had the highest percentage of students who strongly agreed (47) and agreed (40). Additionally, Eagle had the highest percentage of students who strongly agreed (58), however $5 \%$ of her students disagreed that she encouraged in-depth thinking.

Table 2.2 Student perceptions of how their instructor's comments increased their level of engagement in the class.

\begin{tabular}{llllll}
\hline Instructor & \multicolumn{2}{l}{ Level of Agreement } & & \\
\hline & $\begin{array}{l}\text { Strongly } \\
\text { agree }\end{array}$ & Agree & $\begin{array}{l}\text { Neither agree } \\
\text { nor disagree }\end{array}$ & Disagree & $\begin{array}{l}\text { Strongly } \\
\text { Disagree }\end{array}$ \\
Owl & 26 & 21 & 42 & 5 & 0 \\
Jay & 25 & 20 & 45 & 0 & 0 \\
Hawk & 24 & 29 & 33 & 10 & 0 \\
Dove & 47 & 47 & 7 & 0 & 0 \\
Eagle & 58 & 26 & 5 & 5 & 0 \\
Average & 36.2 & 28.6 & 26.4 & 4 & 0 \\
\hline
\end{tabular}


The next set of data (Table 2.2, previous page) indicates the percentage of students "who perceived whether their instructor's comments increased their level of engagement." Overall, students indicated they strongly agreed their instructor's comments increased their level of engagement over the other levels of agreement. Students of Dove and Eagle were more likely to indicate their instructor's comments increased levels of engagement compared to students of the other instructors. Again, Dove's percentages of students who either strongly agreed or agreed was the highest (both at 47\%), while Eagle had the highest percentage who strongly agreed (58\%) — she had 5\% who disagreed that her participation increased levels of engagement.

Table 2.3 Student perceptions of how engaged their instructor was in the discussions.

\begin{tabular}{|c|c|c|c|c|c|}
\hline \multirow[t]{2}{*}{ Instructor } & \multicolumn{5}{|c|}{ Level of Agreement } \\
\hline & $\begin{array}{l}\text { Strongly } \\
\text { agree }\end{array}$ & Agree & $\begin{array}{l}\text { Neither agree } \\
\text { nor disagree }\end{array}$ & Disagree & $\begin{array}{l}\text { Strongly } \\
\text { Disagree }\end{array}$ \\
\hline Owl & 21 & 42 & 32 & 0 & 5 \\
\hline Jay & 30 & 35 & 20 & 5 & 0 \\
\hline Hawk & 29 & 29 & 33 & 5 & 5 \\
\hline Dove & 47 & 47 & 7 & 0 & 0 \\
\hline Eagle & 68 & 21 & 0 & 5 & 0 \\
\hline Average & 39 & 34.8 & 18.4 & 3 & 2 \\
\hline
\end{tabular}

Finally, we asked students to report on how engaged their instructor was in the discussion. Table 2.3 indicates these perceptions. Overall, more students strongly agreed their instructors were engaged in the discussions than any other level of agreement. Again, Dove's and Eagle's students were more likely to strongly agree their instructor was engaged than students in the other sections. Dove's students almost equally believed she was engaged (47\% each) while more than half of Eagle's students (68\%) strongly agreed she was engaged in this discussion.

\section{How Do the Instructor's Perceive Their Roles in These Discussions?}

The final piece of data that we analyzed was results from an instructor survey which asked participants to indicate their perception of their role in these discussions. These data on their general ideas about discussions indicate instructors see themselves more as facilitators rather than direct instructors. For example, when asked how they perceive their role in these discussions, the instructors reported they tried to keep the discussion on track. They perceived their goal as encouraging students, ensuring active participation, providing resources, and being supportive. Additionally, when asked what they hoped their students would receive from their participation in these discussions, they responded:

- We learn best from each other.

- A professional learning community where they are safe to share and can learn from one another. 
Digging Beneath the Surface

- My hope is that they will get information that will impact their instruction in some way. This might include teaching strategies, peer advice, a better understanding of current research, a new perspective.

- Collaboration with other students

\section{Discussion}

Pulling these findings together enables us to begin to more closely examine the role of instructors in asynchronous discussions. We learned not just about what we are saying and how we are saying it but also how instructor participation is perceived by students - as well as ourselves - within the context of the Community of Inquiry framework. We feel by examining this data as a whole raises some interesting patterns and trends that are worth exploring in more depth.

\section{Lack of Cognitive Presence}

When we ask ourselves what instructors are actually saying in these discussions, the results indicate our instructors are really good at giving social comments and even teaching comments but not as good at supporting the cognitive component of the COI model. Our instructors do not use that many cognitive codes. Wang and Chen (2008) assert that online discussions are a great place to practice higher level thinking, but are we supporting this in our responses? We found our instructors were good at validating student comments but not as good at using comments to push discussion further. The instructors in this study also clearly favored the social and teaching parts of the COI framework. All five instructors, regardless of profile, came up with social or teaching codes as the most common type of discursive interaction. This leads us to wonder why our instructors seem to shy away from pushing this discussion into more cognitive domains. We have several hypotheses why this might be the case.

First, we believe that as teachers we are indoctrinated into the discourse of supporting vs. challenging. When we asked the instructors what they believed their role was in asynchronous discussions, they almost uniformly believed that they were facilitators or filled a supportive role. One instructor likened her role to sitting in a circle on the floor with her students-not a very combative location. They emphasized fostering a learning community where students felt safe to share and learn from each other. Perhaps in an online community, one that tends to be less personal in proximity, our instructors felt an extra responsibility to support a positive learning climate which may explain why they used more social codes in their discussion.

Another explanation could be that our instructors, who are mostly classroom teachers, are more comfortable with a discourse based in positive reinforcement. One social code that was common was teacher compliments. Our instructors tended to use teacher compliments to elicit specific responses and to move discussions in specific directions. Our instructors also used teacher elaboration which is a common vehicle through which we teach in the classroom. Personal Experiences is a social code that was used differently amongst the instructors. Some instructors used personal experiences from their direct classrooms while some took them from different parts of their lives. It would be worth exploring these codes in depth to see how these may have contributed to students' responses in these discussions. While perhaps overt cognitive codes were not used, it is possible that some of these teacher and social codes may support other types of desirable discursive interactions.

Another explanation for the lack of cognitive codes could lie in the medium through which the teaching is being delivered: text. These findings made us think deeper about putting things in writing versus saying them out loud in a real time face-to-face discussion. We also wondered why our instructors tended to start many of their posts with teacher compliments. We reflected on our own verbal discussions and do not see ourselves starting each of our teaching conversations face-to-face with compliments. This made us think about the rhetorical style we adopt through a text-based medium and how this is different from face-to-face teaching. We found that in asynchronous discussions our instructors tended to be much 
more complimentary. Perhaps when we put things in writing we have to be more aware of the tone as we don't want to put someone off right away, where as in a face to face discussion we can rely on things like body language and eye contact to make our message come off in a certain way. Following up on these differences in these two discursive styles would be an interesting topic for further examination.

Finally, the reason may lie in the structure of the discussion itself. The forums were relatively open and the questions asked students to engage in readings, digest the material, process and reflect upon the topics. Darabi, et.al (2011) found that the way we structure a discussion can impact the type of cognitive presence supported through this medium. For example, they found that the way we create prompts led to different amount of higher level thinking and engagement. They believed that the conventional method of online discussion in which students respond to isolated questions did not necessarily support cognitive presence where scaffolded discussions, role plays, and debates where more effective in raising the complexity of student responses. Our study seemed to support this finding and also reaffirms that we need to think through these findings as we construct online discussion experiences.

\section{Most Desirable Profile for Interaction}

One of the reasons we were interested in this topic is that we wanted to become better online instructors. With contradictory research on this topic, it was hard for us to know if we should post a lot, a little, or if the difference even mattered. While this study did not set out to determine what the ideal posting ratio looked like, it does start us thinking about what good instructor participation might look like. In this study, we had a wide range of posting styles. Mazzolini and Madison (2003) categorized posting styles as sage on the stage, guide on the side, and ghost in the wings. We believe, however, posting styles are much more complex than these three categories. While this study did not set out to draw relationships between instructor's style and students' behavior; it is worth mentioning that two profiles, Eagle and Dove, tended to favor the most positive results.

Eagle posted 321 comments during this three week period. The students noticed this high number of posts and rated her as the most engaged in discussions (68\% strongly agreed that she was engaged in the discussions). Eagle tended to use more social codes than teaching codes. However, students did not seem to rate her any higher on stimulating their thinking or helping them to be more engaged than Dove. It seems that looking at Eagle's profile of high rate of posting did not seem to matter much for the students. This finding is consistent with previous research identifying the lack of effect the frequency of instructor posting had on student participation (Mazzonlini \& Madison, 2003, 2007). However, this becomes a bit more interesting when we compare Eagle to Dove.

Dove was the second most prolific poster at 143 comments. This frequency put her above the third most frequent poster (Owl) by 109 comments but she still lagged behind Eagle by 178 comments. Despite the difference in amount of posts; however, Dove's and Eagle's students rated them similarly in how their posts supported higher level thinking and kept them engaged (see Tables 2.1 and 2.2).What was interesting about Dove's posts; however, was the ways in which she balanced all three types of codes (Social, Teaching, and Cognitive presence) within the same post. Many of her posts start with a social comment, usually a teaching compliment, where she would make a connection with the learner and build on this connection (she also had a tendency to use student names as openers). She then moved into a teaching comment and finished the post by asking a probing question (see exemplar in the results section). While we do not have data to support how effective this particular style was, we do know students rated her as high in stimulating their engagement and promoting higher level thinking.

These findings led us to the work by Arend (2009) who found that instructors who posted less frequently but with more purpose had a higher level of critical thinking in their discussions. She raised the need to think more about the content of the post versus frequency. She explored what "purposeful" posting looked like. She noticed that contributing specific questions that extended or challenged ideas were effective but when an instructor complimented a student or told them it was a "good point" the conversation tended to end with the compliment. She also asserts that while an instructor still needs to provide a safe and positive environment for students (hence the importance of the social and teaching 
presence codes) that quality posts are more important than quantity. She ends her study by calling for more research around developing facilitation skills for instructors and we hope that our study adds to this conversation.

The issue of infrequent contributions in discussions did come up with a few of our instructors. Hawk posted a mere six times, Jay posted only thirteen times, and Owl posted thirty four times during this time period. These numbers were in sharp contrast to the level of participation by Eagle and Dove. While we agree with Arend (2009) that quality is more important than quantity-we wondered if there should be at least a minimum level of participation required. These low posting rates curiously did not impact student evaluations. While students rated these instructors lower than Eagle and Dove in encouraging in-depth thinking, increasing their level of engagement and being engaged themselves (see tables), student evaluations still were favorable. It is important to recognize there are many different ways to communicate teacher presence in an online class. (Shea, Vickers, \& Hayes, 2010) and its possible students were rating these instructors as acceptable because they were active in other ways (such as timely feedback on assignments, quick answers to emails, and frequent announcements). It is important that research considers the full picture of the course rather than just relying on discussion participation as an indicator of instructor participation-although this is certainly a key area as it relates to instructor presence, student engaging and student satisfaction. Examining how an instructor engages in discussions versus overall in a course would be another area for further research.

\section{Negotiating the Balancing Act}

When we asked students what they sought from their instructors in asynchronous discussions some of the responses included that they wanted an instructor who would critique and lead to further understanding of course content, share experiences and ask probing questions, give more resources on a topic, and provide constructive criticism that would lead to new understanding of content. Students also valued the comments from their instructors that were encouraging, positive, and reaffirming. This leads us to consider the balancing act that one of our instructors mentioned was difficult-how do we simultaneously provide encouragement and also probe to levels of deeper learning? While this is what students reported to have wanted and said we as instructors are doing a good job with social comments (e.g., encouraging, validating) we are falling short on cognitive comments-especially challenging, probing, and elaborating). Using a tool such as the COI will help us see how we are negotiating this balance both in theory and in practice. Research in this area is contradictory and makes finding this balance difficult. Moore (2002) and Swan (2001) believe when instructors have more interaction with students that student satisfaction increases. Mazzolini and Maddison (2003, 2007), on the other hand, questioned the correlation between instructor participation and student posting. By understanding how we can reconcile these competing forces we may be able to begin to more accurately connect our participation with student achievement and satisfaction.

Bliss \& Lawrence (2009) address this in their study on discussion posts and patterns. They found that instructor feedback is an important part of discussion facilitation. They believe that instructors who used affective and supportive comments were more effective than those who posted often but lacked warmth and enthusiasm (p. 28). As they assert, "instructors who are present, attentive, and active in discussion boards can facilitate student participation in discussion forums" (p. 29). This furthers the idea that we need all three parts of the COI framework to be effective but how we employ this framework takes a careful and thoughtful balancing act.

\section{Conclusion}

If online discussions are going to be an important dimension of our teaching it is crucial that we turn our critical lenses inward to better understand our own practice. If we are committed to supporting a constructivist approach to teaching online, one that values the transactional nature of discussions, then becoming more aware of how our participation impacts our teaching will enable us to make the 
connections between our teaching practices and how this effects student learning. This line of research has the potential not only to broaden understanding around online discussions, but also encourage instructor self-reflection on participation and effectiveness.

This study is situated at the nexus of contradictory research about the role of instructor participation in online discussions. We know discussions should be moderated (Wise, et. al., 2006) but we are unclear as to how much participation can be too much (An, Shin, \& Lim, 2009) or if our participation really matters at all (Mazolini \&Madison, 2003,2007). We believe that using a COI framework to help us dig deeper into how we participate in discussions will answer Dixon et al's (2006) call to learn more about the role of the instructor in this medium.

The goal of this research was to more closely examine instructor engagement. For this study we did not look at how instructors' comments impacted student comments. However, now that we have developed an analytical tool and have begun to get a closer look at the complexity of an instructor's engagement in discussion a logical next step would be to look at the impacts of each of these codes on student discussion.

We also feel this study has the potential to lead us in several directions, both practical and theoretical. First, we believe engaging in this type of analysis can help us become more effective online instructors. It is important for us to understand the different things we say and the ways in which we communicate in these online settings. We hope that others can use this analytical tool to look at their own discussions and think about the types of codes that are used most and least frequently as well as the way in which these codes are employed. We also feel this study would provide a good next step for some larger relationship studies to further understand how the instructors' comments do impact student discussions-beyond student perception. Finally, we believe that by digging beneath the surface level of these interactions we can learn more about how this medium supports different types of discursive relationships and can help us create more effective online pedagogy.

\section{References}

Akyol, Z. \& Garrison, D. R. (2011). Understanding cognitive presence in an online and blended community of inquiry: Assessing outcomes and processes for deep approaches to learning. British Journal of Educational Technology, 42, 233-250.

An, H., Shin, S., \& Lim, K. (2009). The effects of different instructor facilitation approaches on students' interactions during asynchronous online discussions. Computers \& Education, 55(3),749-760.

Arbauh, J. B., Cleveland-Innes, M., Diaz, S. R., Garrison, D. R., Ice, P., Richardson, J. C., \& Swan, K. P. (2008). Developing a community of inquiry instruction: Testing a measure of the Community of Inquiry framework using a multi-institutional sample. The Internet and Higher Education, 22, 133-136.

Archibald, D. (2010). Fostering the development of cognitive presence: Initial findings using the Community of Inquiry survey instrument. The Internet and Higher Education, 13, 73-74.

Arend, B. (2009). Encouraging critical thinking in online threaded discussions. The Journal of Educators Online, 6(1), 1-23.

Bliss, C., \& Lawrence, B. (2009). From posts to patterns: A metric to characterize discussion board activity in online courses. Journal of Asynchronous Learning Networks, 13(2), 15-32.

Cazden, C. (1988). Classroom discourse: The language of teaching and learning. Portsmouth, NH: Heinemann

Carr-Chellman, A., \& Duchastel, P. (2000). The ideal online course. British Journal of Educational Technology, 31(3), 229-241. 
Darabi, A., Arrastia, M.C., Nelson, D.W., Cornille, T., \& Liang, X. (2011). Cognitive presence in asynchronous online learning: A comparison of four discussion strategies. Journal of Computer Assisted Learning, 27, 216-227.

Dixson, M., Kuhlhorst, M., \& Reiff, A. (2006).Creating effective online discussions: Optimal instructor and student roles. Journal of Asynchronous Learning Networks, 10(4), 15-28.

Fauske, J., \& Wade, S.E., (2003-2004). Research to practice online: Conditions that foster democracy, community, and critical thinking in computer-mediated discussions. Journal of Research on Technology in Education, 36(2), 137-153.

Garrison, D. R., , Anderson, T. \& Archer, W. (2001). Critical thinking, cognitive presence, and computer conferencing in distance education. American Journal of Distance Education, 15(1), 7-23.

Garrison, D. R., Anderson, T., \& Archer, W. (2010). The first decade of the community of inquiry framework: A retrospective. The Internet and Higher Education, 13, 5-9.

Garrison, D. R., \& Arbaugh, J. B. (2007). Researching the community of inquiry framework: Review, issues, and future directions. The Internet and Higher Education, 10, 157-172.

Henning, W. (2004). Everyday cognition and situated learning. In Handbook of Research on Educational Communications and Technology (2nd ed.), Ed. D. Jonassen, 143-168. Mahwah, NJ: Erlbaum.

Hew, K. F., Cheung, W.S., \& Ng, C.S.L. (2010). Student contribution in asynchronous online discussion: A review of the research and empirical exploration. Instructional Science, 38, 571-606.

Hirumi, A., \& Bermudez, A.B. (1996). Interactivity, distance education, and instructional systems design converge on the information superhighway. Journal of Research on Computing in Education, 29(1), 1-16.

Jiang, M. \& E. Ting (2009). A study of factors influencing students’ perceived learning in a webbased course environment. International Journal of Educational Telecommunications 6(4), 317-338.

King, K. P. (2002). Identifying success in online teacher education and professional development. Internet and Higher Education, 5, 231-246.

Koory, M.A. (2003). Differences in learning outcomes for the online and face to face versions of “An introduction to Shakespeare.” Journal of Asynchronous Learning Networks, 72(2).

$\mathrm{Li}$, Q. (2003). Would we teach without technology? A professor's experience of teaching mathematics education incorporating the internet. Educational Research, 45(1),61-77.

Mazzolini, M., \& Maddison, S. (2007). When to jump in: The role of the instructor in online discussion forums. Computers \& Education, 49(2), 193-213.

Mazzolini, M., \& Maddison, S. (2003). Sage, guide, or ghost? The effect of instructor intervention on student participation in online discussion forums. Computers \& Education, 40(3), 237-53.

Meyer, K.A. (2003). Evaluating online discussions: Four different frames of analysis._Journal of Asynchronous Learning Networks, 8(2), 101-114.

Nandi, D., Hamilton, M., \& Harland, J. (2012). Evaluating the quality of interaction in asynchronous discussion forums in fully online courses. Distance Education, 33(1). 5-30.

Palloff, R., \& Pratt, K. (1999). Building learning communities in cyberspace: Effective strategies for the online classroom. San Francisco: Josey-Bass. 
Peterson, S. S., \& Slotta, J. (2009). Saying yes to online learning: A first time experience teaching an online graduate course in literacy education. Literacy Research and $\quad$ Instruction, 48, 120136.

Rourke, L., \& Kanuka, H. (2009). Learning in communities of inquiry: A review of the literature. Journal of Distance Education, 23, 19-47.

Shea, P. (2006). A study of students' sense of learning community in online environments. Journal of Asynchronous Learning Networks, 10, 35-44.

Shea, P., Li, C. A., \& Pickett, A. (2006). A study of teaching presence and student sense of learning community in fully online and web-enhanced college courses. The Internet and Higher Education, 9, 175-190.

Shea, P., Vickers, J., \& Hayes, S. (2010). Online instructional effort measured through the lens of teaching presence in the Community of Inquiry framework: A re-examination of measures and approach. International Review of Research in Open \& Distance Learning, 11.

Strauss, A. \& Corbin, J. (1994). Grounded theory methodology: An overview, In: Handbook of Qualitative Research (Denzin, N., K. and Lincoln, Y.,S., Eds.). Sage Publications, London, 1-18.

Swan, K. (2001). Virtual interaction: Design factors affecting student satisfaction and perceived learning in asynchronous online courses. Distance Education, 22(2), 306-31

Swan, K., Shih, L. F. (2005). On the nature and development of social presence in online course discussions. Journal of Asynchronous Learning Networks, 9, 115-136.

Thomas, M. (2002). Learning within incoherent structures: The space of online discussion forums. Journal of Computer Assisted Learning, 18(3), 351-66.

Vlachopoulos, P., \& Cowan, J. (2010). Reconceptualising moderation in asynchronous online discussions using grounded theory. Distance Education, 31(1). 23-36.

Vonderwell, S., \& Zachariah, S. (2005). Factors that influence participation in online learning. Journal of Research on Technology in Education, 38(2), 213-229.

Vygotsky, L. S. (1978). Mind in society: The development of higher psychological processes. Cambridge, MA: Harvard University Press.

Wang Y., Chen, V., D. (2008) Essential elements in designing online discussions to promote cognitive presence- A practical experience. Journal of Asynchronous Learning Networks, 12(3-4), 157-177.

Wise, K., Hamman, B., \& Thorson, K. (2006). Moderation, response rate, and message interactivity: Features of online communities and their effects on intent to participate. Journal of Computer-Mediated Communication, 12(1), 24-41.

Wu, D., \& Hiltz, S. R. (2004). Predicting learning from asynchronous online discussions. Journal of Asynchronous Learning Networks, 8. Retrieved March, 5, 2013, from http://www.sloan-c.org/publications/jaln/v8n4/index.asp 